\title{
参考資料
}

\section{$10 \mathrm{MV}$ X線胸部照射における Modulex 放射線治療計画システムの性能評価}

\author{
奈 良 鉄 造 \\ (財)双人会厚生病院循環器腫瘍センター放射線部
}

（論文受理 1987 年 7 月 22 日）

（最終論文受理 1988 年 8 月19日）

(Code No. 713, 700.2)

Key words: Radiotherapy, Treatment planning, Inhomogeneity, $10 \mathrm{MV}$ X-ray

\section{PERFORMANCE EVALUATION OF MODULEX TREATMENT PLANNING SYSTEM FOR 10-MV PHOTON BEAM DOSE CALCULATIONS IN THORAX PHANTOMS}

\author{
Tetsuzo NARA \\ Joint Research Center for Circulator and Cancer, Kousei Hospital
}

(Article received ; Jul., 22, 1987)

\section{1. 緒言}

放射線治療において，標的容積を含む被照射体内にお ける吸収線量の算出はより正確であることが望まれる. 病巣線量計算の精度に影響を与える諸因子として標準水 ファントムにおける線量測定, 解剖学的情報, 不均質補 正計算, 患者の整位等がある.

今日，線量および等線量分布の計算には治療計画用コ ンピュータが多く用いられている，特に，原体照射にお ける線量分布計算や三次元表示の作成にはコンピュータ 利用が不可欠である．今後，ますますその利用価值が高 くなると思われる.しかしながら, この場合, コンピュ ー夕による線量計算精度に関する問題は重要である。こ れまで,これに関する報告1)-4) (数多くなされている.線 量計算する上で重要な問題の一つに，不均質組織による 線量補正がある.これまでに，色々な補正法が報告 ${ }^{51-7) さ ~}$ れている。それらには，散乱の影響を無視した補正法と して，実効 SSD 法，TAR 法および実効減弱法がある。
次に散乱の影響を考慮した補正法として, 散乱補正係数 法, べき乗 TAR 法 (Batho 法), 等価 TAR 法および等 線量移動法がある.

現在, われわれが行っている $10 \mathrm{MV} \mathrm{X}$ 線治療計画は CMS 社製 Modulex (ソフトウェア：リレース2.3) シス テムに従っている.このシステムの不均質補正には TAR 法が採用されている. 日本放射線技術学会治療委 員会による治療計画用電算機の精度調査報告8) (1983年) によれば，コンピュータの多くは実効 SSD 法 (77\%) を 用いており，等価 TAR 法は約 $8 \%$ あるあという.

われわれは簡単な胸部不均質ファントムを用いて10 MV X線照射において特に胸壁厚および照射野の変化 がいかにコンピュータによる計算值と電離箱による実測 値に影響を与えるかをビーム中心軸上で調べ，このコン ピュータの性能評価を行った。

\section{2. 実験方法}

実験に使用したライナック装置は三菱電機製 ML-15 
M III型（10 MV X 線）である. 当施設の Modulexに は，直接そのライナック装置を使用して得られた基本ビ 一ムデータが入力されておらず，同機種のあるライナッ ク装置で得られたビームデータが入力されている。そこ で，そのビームデータのひとつである水中の深部量百分 率について検討した. 水と等価である $\mathrm{Mix}-\mathrm{Dp}$ ファント ム $\left(30 \times 30 \mathrm{~cm}^{2}, \rho=1.01 \mathrm{~g} / \mathrm{cm}^{3}\right)$ を用いて, 当施設のラ イナック装置による深部量百分率とコンピュータによる 計算値（以下，計算值と略す）との比較を行った。なお， Mix-Dp ファントムの密度 $\left(\rho=1.01 \mathrm{~g} / \mathrm{cm}^{3}\right)$ は重量およ び容積でもって調べた。よって，実験に用いた $\mathrm{Mix}-\mathrm{Dp}$ ファントムは水とほとんど等価であることがわかった。

実験に使用した胸部ファントムは軟組織, 肺組織，お よび軟組織の三層からなっている。軟組織には $\mathrm{Mix}-\mathrm{Dp}$ 板 $\left(30 \times 30 \mathrm{~cm}^{2}, \rho=1.01 \mathrm{~g} / \mathrm{cm}^{3}\right)$, 肺にはコルク板 $(30 \times$ $\left.30 \mathrm{~cm}^{2}, \rho=0.23 \mathrm{~g} / \mathrm{cm}^{3}\right)$ を用いた．肺の厚さは $12 \mathrm{~cm}$, 後壁の厚さは $8 \mathrm{~cm}$ とそれぞれ一定にし,前壁の厚さを 1 $\mathrm{cm}, 2 \mathrm{~cm}, 4 \mathrm{~cm}$ と変化させた.

ファントム内の線量測定には $0.6 \mathrm{~cm}^{3}$ 電離箱 (Farmer 2570）を用いた．各不均質ファントム内深部量百分率は， それぞれの照射に対してその照射野と同じ照射野で得ら れる Mix-Dp ファントム中のピーク深 $(2.5 \mathrm{~cm})$ の線量 值を $100 \%$ にした值である。

$\mathrm{Mix}-\mathrm{Dp}$ ファントムおよび不均質ファントム内での 測定点は電離箱中心とし, 各々の深さにおける吸収線量 にはイオン再結合補正9)，を施した。ただし，変位係数は Mix-Dp 内およびコルク内で変わらないものとした。 よ って，深部量百分率には変位係数は影響を与えない。

Farmer 電離箱によるファントム内線量值の繰り返し による相対誤差は土1\%以内に納まった。

\section{3. 結果および考察}

Fig. 1 は照射野 $5 \times 5 \mathrm{~cm}^{2}$ と $15 \times 15 \mathrm{~cm}^{2} （ \mathrm{SSD}=100$ $\mathrm{cm}$ ）に対する $\mathrm{Mix}-\mathrm{Dp}$ ファントム内の深部量百分率を 表す．黑丸は実測値である．実線と 1 点鎖線はそれらの 実測値をもとに作った．点線と 2 点鎖線は計算値で作っ たものである。実測值に対する計算值の相対誤差は $5 \times 5$ $\mathrm{cm}^{2}$ で平均 $\pm 1.4 \%$ (範囲: $-0.3 \sim+2.9 \%$ ), $15 \times 15 \mathrm{~cm}^{2}$ では平均 $\pm 0.9 \%$ (範囲： $-1.2 \sim+1.7 \%$ )である。照射 野が $5 \times 5 \mathrm{~cm}^{2}$ の場合の相対誤差が比較的大きいが, それ でも土 $3 \%$ 以内に納まっている.

Fig. 2(a)—(c)に前壁厚が $1 \mathrm{~cm}, 2 \mathrm{~cm}, 4 \mathrm{~cm}$ である胸部 ファントムの各々に対して照射野 $5 \times 5 \mathrm{~cm}^{2}$ と $15 \times 15$ $\mathrm{cm}^{2}(\mathrm{SSD}=100 \mathrm{~cm})$ に打ける深部量百分率を示す。実線

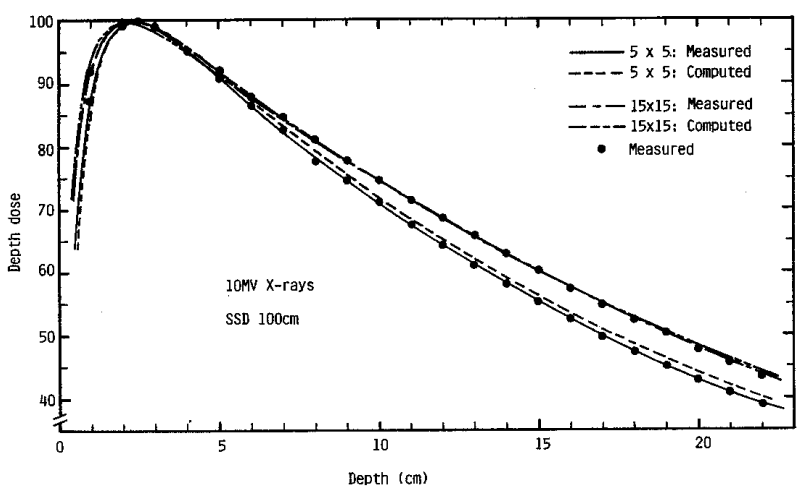

Fig. 1 Computed and measured depth-doses for $10 \mathrm{MV} \mathrm{x}$-ray $5 \times 5$ and $15 \times 15 \mathrm{~cm}^{2}$ fields at SSD $100 \mathrm{~cm}$ in a semi-infinite Mix-Dp phantom.

と 1 点鎖線は実測值であり，点線と 2 点鎖線は計算值で ある。

（1）照射野 $5 \times 5 \mathrm{~cm}^{2}$ の場合

まず肺内における実測値に対する計算值の相対誤差に ついて述べる．前壁厚 $1 \mathrm{~cm}$ [Fig. 2 (a)] を有する胸部フ アントムでは, 深さ $10 \mathrm{~cm}$ の点で約+16\%である.前壁厚 $4 \mathrm{~cm}$ [Fig. 2 (b)] を有する胸部ファントムでは，深さ11 $\mathrm{cm}$ の点で約 $+22 \%$ である．照射野 $5 \times 5 \mathrm{~cm}^{2}$ では前壁厚 が厚くなるほど，全般的その相対誤差は大きくなる，そ の理由として, 前壁の軟組織からの散乱線量が原因して いると思われる。

次に肺と後壁の境界点について述べる，前壁厚 $1 \mathrm{~cm}$ [Fig. 2 (a)] を有する胸部ファントムでは約 $+10 \%$ の相対 誤差が生じ，また前壁厚 $4 \mathrm{~cm}$ [Fig. 2 (c) ] を有する胸部 ファントムでは約 $+17 \%$ の相対誤差がそれぞれ生じてい る.このように異種物質境界では, 肺内と同様に計算值 は実測值に対してかなり大きな值を表す，ただし，境界 点については, 測定に用いている電離箱の容積が大きい ために必ずしも正確な值ではないと思う。

最後に後壁内について述べる. 前壁厚 $1 \mathrm{~cm}$ [Fig. 2 (a)] を有する胸部ファントムにおいては，深さ $16 \mathrm{~cm}$ の点で 約 $-0.1 \%$ ，前壁厚 $4 \mathrm{~cm}$ [Fig. 2 (c)] を有する胸部ファン トムにおいては，樑さ $19 \mathrm{~cm}$ の点で約 $+4 \%$ の相対誤差 をそれぞれ有する。このように前壁が厚くなる程に，後 壁内においても実測值に対する計算值の相対誤差は大き くなる.

前壁厚 $1 \mathrm{~cm}$ [Fig. 2 (a) ] を有する胸部ファントムにお いては，相対誤差は土 $3 \%$ 以内の精度に保たれている。

（2）照射野 $15 \times 15 \mathrm{~cm}^{2}$ の場合

照射野 $15 \times 15 \mathrm{~cm}^{2}$ では Fig. 2 (a)一(c) 上り全ての点に おいて，実測值に対する計算值の相対誤差は照射野 $5 \times 5$ 

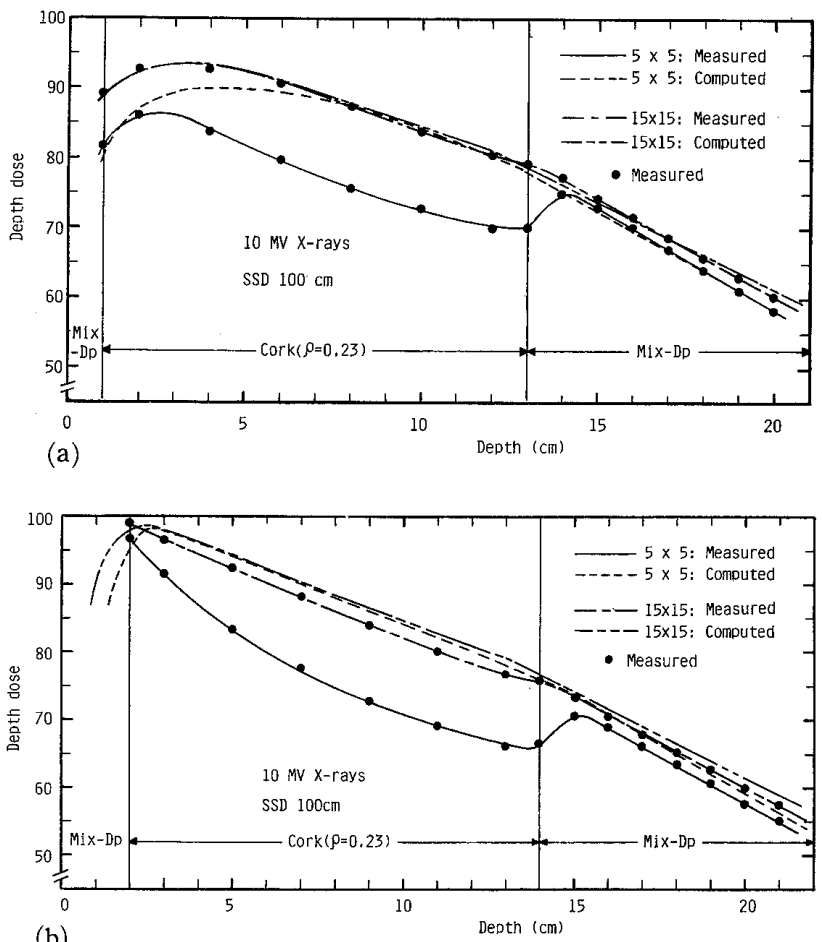

(b)

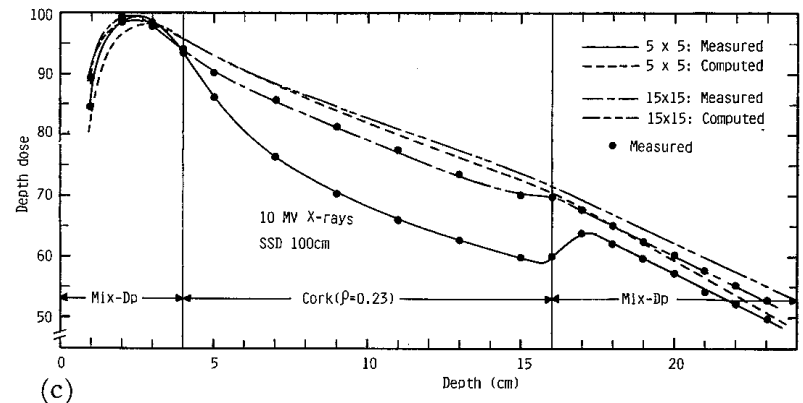

(c)

Fig. 2 Computed and measured depth-doses for $10 \mathrm{MV} \mathrm{x}$-ray $5 \times 5$ and $15 \times 15 \mathrm{~cm}^{2}$ fields at SSD $100 \mathrm{~cm}$ in three thorax phantoms. The phantoms are constructed with (a) a front wall of $1-\mathrm{cm}$ thickness, a lung of $12-\mathrm{cm}$ thickness, and a back wall of $8^{-}$ $\mathrm{cm}$ thickness, (b) a front wall of $2-\mathrm{cm}$ thickness, a lung of $12-\mathrm{cm}$ thickness, and a back wall of 8-cm thickness, and (c) a front wall of $4-\mathrm{cm}$ thickness, a lung of 12 $-\mathrm{cm}$ thickness, and a back wall of $8-\mathrm{cm}$ thickness.

$\mathrm{cm}^{2}$ に比べてそれほど，大きくなっていないことがわか る.

前壁厚 $1 \mathrm{~cm}$ [Fig. 2(a)] および前壁厚 $2 \mathrm{~cm}$ [Fig. 2(b)] を有する胸部ファントムに対しては，全ての点（肺内お よび異種物質境界，そして後壁内）において，計算値は 実測值に対して $3 \%$ 以内の精度に保たれている．照射 野 $10 \times 10 \mathrm{~cm}^{2}$ においても同様の結果が得られた。
前壁厚 $4 \mathrm{~cm}$ [Fig. 2(c)］を有する胸部ファントムで は, 深さ $13 \mathrm{~cm}$ の点 (肺内) で約+ $6 \%$, 深さ $16 \mathrm{~cm}$ の点 (肺と後壁境界) で約 $+3 \%$ ，および深さ $21 \mathrm{~cm}$ の点 (後 壁内）で約＋5\%の最大相対誤差をそれぞれ有する。

当施設で用いている放射線治療計画用コンピュータは 不均質補正法に TAR 法を用いている.しかし，この方法 は水と異なる媒体内での一次吸収線量および散乱吸収線 量の算出を必ずしも適確に行えない. Fig. 2 (a)一-(c)に見 られるように小照射野に扔いて，後壁内で再びビルドア ップが生じていること，また特に肺内におていては，実測 值と計算值とが大きく異なることに注目しなければなら ない.これらの現象は, 肺内において前方および側方電 子平衡が大きく崩れてしまうために抗こる．当施設の Modulexに入力されている基本ビームデータの誤差だ けでは，到底説明できないものである，つまり，TAR 法 の不均質補正そのものの精度に起因している。

\section{4. 結論}

1. 照射野 $5 \times 5 \mathrm{~cm}^{2}(\mathrm{SSD}=100 \mathrm{~cm})$ では TAR 法の不 均質補正による計算値は実測値に対して相対誤差がかな り大きい.

2. 照射野 $10 \times 10 \mathrm{~cm}^{2}(\mathrm{SSD}=100 \mathrm{~cm})$ 以上では前壁厚 $1 \mathrm{~cm}$ から $2 \mathrm{~cm}$ 位であれば，TAR 法によるコンピュー 夕による計算值は実測值に対して $3 \%$ 以下の相対誤差 になる。

\section{文献}

1）渡部洋一：子宮頸癌の放射線治療における照射精度, 日放技学誌，42(2)，264-289，(1986)。

2）泉隆：Thrac-IIIの線量と線量分布の精度, 日放 技学誌，38(4)，455-463，(1982).

3）近藤康雄, 他：放射線治療計画におけるコンピュー 夕処理とその精度について, 日放技学誌, 38(4), 464 $-471,(1982)$.

4）伊藤慎弥：治療計画用電算機による線量分布の精度, 日放技学誌，38(4)，472-479，(1982).

5）尾内能夫, 川島勝弘：放射線医学大系34, 放射線物 理学, 192-194, 中山書店, (1984).

6）岩崎 晃, 他：密度尺度理論に基づいた微分 SAR 式及び微分 BSF 式を用いた不均質体内の線量を算 出する方法, 日医放会誌, 44(3)，503-516, (1984).

7）Purdy J.A.：放射線治療におけるコンピュータの応 用，第10回 PC user group meeting text，(1983). 
8）放射線治療技術委員会：治療計画用電算機の精度調 査報告，日放技学誌，39(3)，372-384，(1983)。

9）日本医学放射線学会物理部会：放射線治療における
高エネルギーX線および電子線の吸収線量の標準測 定法，通商産業研究社，（1986）。

\section{$\mathrm{BaSO}_{4}$ 造影剤自動遠隔注排装置} enema teleflator

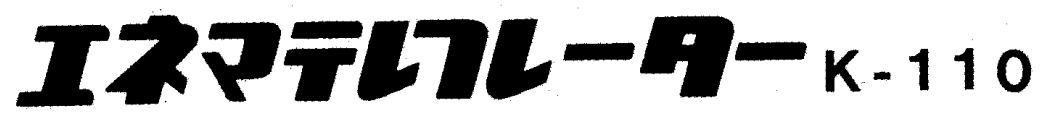

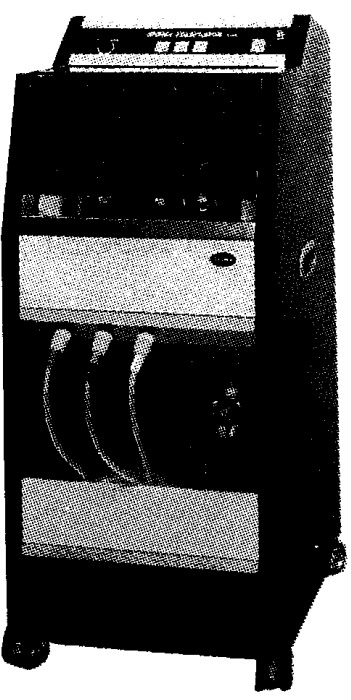

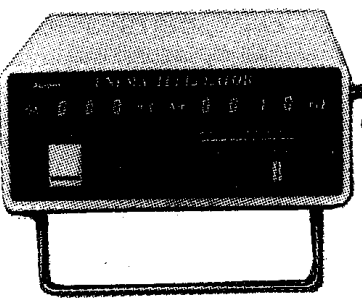

コントロールユニット

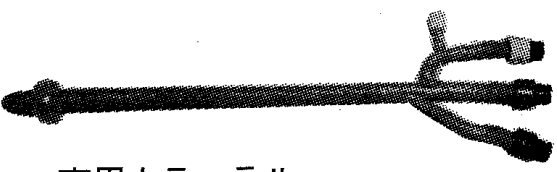

専用カテーテル ( 3 W 4 G型)

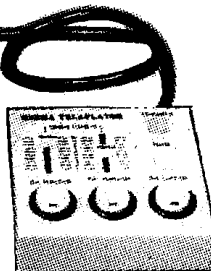

(多方向透視台用 S-200・T-200もあります)
1. 高性能メカを内蔵したコンパ クト型で、取付工事も不要で、 移動も简単にできます。

2. 遠隔操作で術者の被曝がなく、 検査時間が短縮されます。

3．バリウムや空気を操作室から 注排でき、注入速度や注入量を 自由にコントロールできます。

4. 空気注入圧は、二種類の圧力 計による二重安全装置を关なえ ており、注入はシリンダ一方式 により安全な注入が行なえます。 5. 専用力テーテルはソケットに より交換でき、能率的に連続検 查ができます。

6. 洗浄機構内蔵で、検査後の機 械洗浄が旊単にできます。

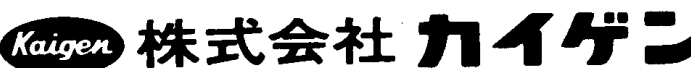

大阪市東区道修町 3 丁目 9 番地
大阪営業所 $\mathbf{0}(06)$ 202-8975(直) 名古屋営業所 $\mathbf{0}(052) 834-1011$ (代) 札㹸営業所 $\mathbf{2}(011) 631-3249$ 広島営業所 $\boldsymbol{\sigma}(082) 291-1902$ 横浜出張所 $\boldsymbol{\approx}$ (045) 241-8668
東京営業所 天(03) 438-2511代) 福岡営業所 $\boldsymbol{\sigma}$ (092) 441-0832(代) 仙台営業所 (0222) 91-3622 金沢営業所 $\boldsymbol{\sigma}(0762) 68-4125$ 